\title{
Pre-Print
}

Permission Granted to Authors to Post Online by The Great Commission Research Journal.

\section{Innovation in Churches: A Theoretical Framework}

David R. Dunaetz, Editor

\begin{abstract}
The impact of the COVID-19 pandemic and the many changes in the present socio-cultural context point to the importance of innovation in churches. A theoretical framework for understanding innovation in churches is presented, featuring 6 key elements. These elements include the cultural context of the church and the church's target audience, a culture of innovation within the church, innovations in church programs, processes, and personnel, social capital (social ties) which permits church members to navigate the changes associated with innovation, program loss (that which is lost when programs change), and progress toward the church's goals. The church's goals and the church's context determine which innovations would be most appropriate. A culture of innovation and strong social ties permit innovations to be implemented successfully. Program losses may reflect aspects of the church's goals that are neglected when innovations are implemented.
\end{abstract}

The COVID-19 pandemic of 2020-2021 has demonstrated how important innovations in churches are. For most churches, especially in the developed world with strict procedures in place to protect public health, virtually all programs and meetings in their existing form stopped due to stay-at-home orders which varied in frequency and duration according to 
the severity of the pandemic and policies of local, state, and national powerholders. Churches were forced to innovate, as described in some of the articles in this issue of the Great Commission Research Journal (e.g., Franks, 2021; Ransom \& Moody, 2021). These innovations all represent stories of relative success during trying times. However, not all churches implemented successful innovations and are still trying to recover from the interruptions caused by the pandemic.

To better understand innovation in churches (when it is necessary, what constitutes a successful innovation, what their purpose should be, and what contributes to their success and failure), a model is presented here based on empirical research done both in organizations in general (e.g., Anderson et al., 2014; Gopalakrishnan \& Damanpour, 1997; Hurley \& Hult, 1998) and in churches specifically (e.g., Covarrubias et al., 2021; Powell \& Pepper, 2018). The goal of presenting this model is to help church leaders think clearly about innovation, analyze the role of innovation in their churches, and make changes to more effectively accomplish the Great Commission that Jesus gave us (Matt. 28:18-20).

\section{A Model of Innovation in Churches}

A theoretical framework for understanding innovation in churches is presented in the model in Figure 1; the model has six main elements. At the center lies innovation itself, the new ideas, programs, and processes that are introduced into the life of a local church. The principal antecedent to innovation is a culture of innovation within the church, which makes innovation possible. The desired outcome of innovation is progress towards accomplishing the mission of the church. However, if elements of existing programs are lost in the process of innovation, this program loss can reduce, or even erase any progress made toward fulfilling the church's mission. Moreover, the strength of the relationship between innovation and progress is influenced by the social ties linking church members. When church members have strong social ties with each other, innovation is more likely to have a positive effect than when the church members only have weak social ties. All of this lies within a specific cultural context.

This model does not seek to explain all the complexities associated with innovation. Some factors are not included in this model (e.g., the possibility of conflicts escalating and damaging relationships). However, the model seeks to explain how several well-researched phenomena relate to innovation in the context of churches. 


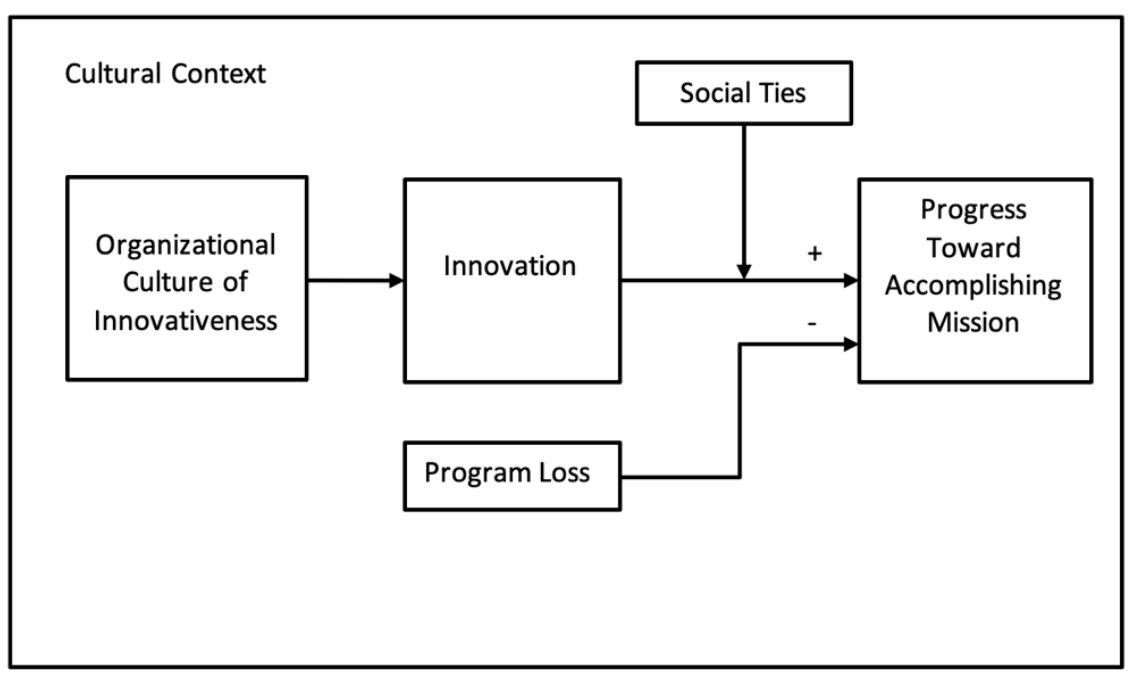

Figure 1. A Theoretical Model of Innovation in Churches

\section{Innovation}

Church innovation can be defined as the introduction of "new processes, products, or ideas" into the church (Hult et al., 2004, p. 429). In churches, the most visible forms of innovation are new programs and activities but may also include the introduction of new technologies (as was common during the COVID-19 pandemic), new administrative structures (such as adding staff), or new processes (such as determining who will be on a church board and other forms of leadership selection).

Innovation can be conceived as a two-step process, the first stage consisting of the generation of new ideas and the second stage consisting of implementation. The first stage has much overlap with creativity. However, creativity is typically considered an individual activity whereas innovation occurs at the organizational level, or at least at the group level within organizations (Adams et al., 2004). The creation of new ideas may also occur outside the church, but innovation requires adapting the idea to the church's context. The second stage, implementation, consists of making the new program, activity, or process a reality within the organization. The distinction between these stages may be somewhat superficial because the creation and implementation of new processes is not a linear process. As soon as leaders start implementing an idea, they may realize that it needs to be modified, requiring the generation of new ideas; this process may continue back and forth indefinitely.

Church innovation can take many forms. Several dimensions are 
useful for understanding the types of innovations that have been made in the past and those which can be made now.

Product versus Process Innovations. Product innovations (Fritsch \& Meschede, 2001; Gopalakrishnan \& Damanpour, 1997) are new products that benefit an organization's clients or service recipients. In churches, these new products would typically be programs (e.g., Awana, Sunday School, or training for small group leaders), activities (e.g., worship services or small group Bible studies), and services (e.g., food distribution or neighborhood tutoring) that benefit either people within the church community or those in the broader community surrounding the church. Digital monastic communities (Anderson, 2021) and the interactive, online children's ministry (Norregaard \& Ng, 2021) described in this issue are product innovations. To generate ideas concerning product innovations, it is useful to think of the main programs or area of ministry of the church. For examples, some churches may view their focal ministries as Worship, Teaching, Evangelism, Missions, and Fellowship. The questions "What are new ways we can worship?" or "What are ways we can improve evangelism in the church?" are questions that can lead to product innovations.

Process innovations, on the other hand, are new tools, technologies, or knowledge that help organizations to improve or create new programs, activities, or services. During the pandemic, most innovations in churches were process innovations. Examples include the use of Zoom and Facebook Live for broadcasting worship services or meeting together in small groups (Ransom \& Moody, 2021; Sellers, 2021). When the pandemic hit, in order to maintain, or perhaps even improve, existing programs, new processes needed to be introduced (e.g., online broadcasting and online meetings) into churches.

Radical versus Incremental Innovations. Radical innovations are a clear departure from what was done previously whereas incremental innovations improve what is currently being done (Gopalakrishnan \& Damanpour, 1997). Most innovations in churches, apart from times of crisis, are incremental with the goal of gradually improving or adjusting a program in light of new insights, new technologies, or cultural changes. Radical innovations in churches are less common; examples might include training individuals in personal evangelism (popular in the 1970 s and 1980s), the introduction of a small groups ministry, or the replacement of time-tested hymns with contemporary worship songs in worship. However, all innovations can be placed along a radical-incremental spectrum and what seems radical in one context may be simply incremental in another. In general, any creative idea that is greeted with 
"We've never done it that way before" may be considered a radical innovation in its context (Neighbour, 1973). The likelihood of a radical innovation being successfully implemented is lower than that of an incremental innovation. Organizational openness and social ties (described later in this discussion) are especially important factors influencing the successful implementation of all innovations, and especially of radical innovations.

Technical versus Administrative Innovations. When we think of innovations in churches, we usually think of visible changes in programs, activities, and services. These visible innovations are known as technical innovations because they directly affect what the church does to accomplish its mission (Gopalakrishnan \& Damanpour, 1997; Jaskyte, 2011). However, innovations may also be invisible, affecting only how employees of the organization relate to each other and to the organization; these can be classified as administrative innovations. Administrative innovations may include hiring staff who do not appear publicly in the church's ministry, changing the church bylaws or organizational structure (who reports to whom), or creating new human resources practices. Innovative human resource practices may include training for staff, employing additional people in decision-making processes, creating awards for specific types of employee behavior, flexible work hours, placing an emphasis on job variety, or providing greater autonomy (Anderson et al., 2014). Any change in leadership behavior that is not directly seen in the programs, activities, or services offered by the church can be viewed as an administrative innovation. To develop administrative innovations, leaders can ask themselves "How can I treat people differently to more effectively carry out the church's mission?"

\section{Progress Toward Mission Accomplishment}

The goal of innovation in a church should be to move towards accomplishing the mission that God has given the church. Without a clear understanding of the church's mission, the choice of what innovations to implement will be muddled. Churches often have mission statements (Church Relevance, 2013; Mullane, 2002) which might specifically focus on fulfilling the Great Commission (Matt. 28:18-20) or a broader description of Christian responsibility. Such a statement provides a standard by which programs and methods can be assessed. Because church innovation is typically the introduction of new programs and activities, a church's mission statement also provides a standard by which innovations can be evaluated. Innovations that are likely to contribute to accomplishing the church's mission should be adopted while those that do 
not contribute to it should not be prioritized.

In practice, the mission statement of the church may simply reflect an idealized view of the church's values and may be used more to project a specific public image (Mullane, 2002; Swales \& Rogers, 1995) than to evaluate programs and activities. Other values may play an important role, sometimes a much more important role, in determining the innovations that are adopted. These values may vary in their legitimacy from a biblical point of view. Providing for the needs of the church staff and their families and maintaining the status quo financially (e.g., not offending large donors) may be among the highest priorities in a church and the determining factor concerning some innovations.

On the less honorable end of questionable factors influencing whether an innovation should be adopted in a church are the leaders' ego needs. Although humility is one of the most important virtues in the Bible (e.g., I Pet 5:5-6, James 4:6-10, Mark 10:42-45), churches, especially large churches, like all organizations, tend to attract potential leaders who may be relatively narcissistic, pursuing their own status and recognition (Campbell et al., 2011; Dunaetz, Jung, et al., 2018; Grijalva et al., 2015; Twenge \& Campbell, 2009; Zondag, 2004). Such leaders may adopt innovations that will make them look better because they want to appear on the cutting edge, because they feel entitled to the personal benefits that the innovation may bring them, or because there is some other factor associated with the innovation that grants them status in the eyes of others (Grapsas et al., 2020; Kirby, 2021; Puls, 2020a, 2020b). Nevertheless, church leaders need to fight against these human tendencies and do their best to "seek first the Kingdom of God" (Matt. 6:33) when evaluating what innovations to implement.

\section{Cultural Context}

This model of church innovation (Figure 1) sets all the specific elements directly associated with innovation within a cultural context. No innovation can be made, nor can its value be determined, apart from its cultural context. The most obvious role of culture in innovation concerns technology. For the last several millennia, humans have regularly made advances in technology, a progress which has especially accelerated during the past century (Ellul, 1954). The technology available within a culture is strongly linked to the technology available for church innovations, ranging from the advances in gothic architecture permitting more light into church buildings during the medieval period to the use of LED lighting for mood enhancement in contemporary times. Sometimes innovation is very closely linked to the latest technology; if the COVID-19 pandemic had 
started a year earlier, church innovation might have looked quite different since Zoom video conferencing would have been much less available (Bowles, 2021).

But the cultural context is far more than technology; it includes all the beliefs and values that are generally held by a group of people (Hofstede, 1980; Schein, 2004). The impact of any innovation (positive or negative, weak or strong) will depend on the culture of the people impacted by the innovation, both inside and outside of the church. This culture may include the social and political trends as well as the academic and intellectual issues considered important. Church leaders must evaluate a potential innovation in light of the culture of the intended audience as well as the cultural changes that are taking place in this audience. Some of the macro trends occurring in the world are increased individualism as standards of living rise (Santos et al., 2017; Twenge \& Campbell, 2018) and increased political polarization as social media provides echo chambers (Colleoni et al., 2014) and opportunities for trench warfare where debaters on each side of a debate refuse to listen to each other (Karlsen et al., 2017), convincing users (or at least themselves) that no reasonable person would hold an opinion different than their own.

Innovations must therefore respond to the real issues that people are dealing with in this new cultural context, issues similar to those faced by previous generations, but in a cultural context where materialism and online communication play a greater role. Such contemporary issues include loneliness, lack of social skills, obesity, more frequent mental disorders, and dealing with conspiracy theories. Innovations that include new programs and activities to respond to these complex issues will make the gospel more credible (Dunaetz, 2016; Pornpitakpan, 2004) and will enable churches to better accomplish their mission.

\section{A Cultural of Innovativeness within in the Church}

Organizational culture reflects the beliefs and behaviors that are generally assumed to be appropriate in a specific organization (Schein, 2004). Churches, like all organizations, tend to develop specific ways of doing things that distinguish them from other churches. A culture of innovativeness is one of the most important predictors of innovation in churches; without such a culture, innovation is far less likely (Ruvio et al., 2014; see also Covarrubias et al., 2021, in this issue). A culture of innovation "provides environmental support for the continuous generation of new ideas and products over time" (Ruvio et al., 2014, p. 1004). In a study of 2800 Australian churches, Powell and Pepper (2018) found that a culture of innovativeness is associated with better-appreciated worship services, 
stronger relationships among members, stronger personal commitment of leaders to innovation, but only very weakly (and negatively) to church size.

Empirical research has discovered various elements of organizational culture which predict innovations (Hult et al., 2004; Hurley \& Hult, 1998; Hurley et al., 2005; Ruvio et al., 2014). These include creativity, organizational openness to new ideas, an orientation toward the future, a willingness to take risks, and proactiveness (Ruvio et al., 2014). All of these can be found in churches; the degree to which they are found is likely to predict how innovative a church will be.

Creativity. Whereas innovation is the adaptation and implementation of new ideas, new programs, and new processes in a specific context, creativity is the generation of the ideas which paves the way for adaptation and implementation. Creativity is the initial process, while adaptation and innovation are subsequent processes for introducing new and improved programs, processes, and other activities in a church (Anderson et al., 2014; Ruvio et al., 2014). Creativity can be defined as "the generation of novel and useful ideas" (Anderson et al., 2014, p. 1298). Such ideas may or may not be implemented, but they must be new and useful to be considered creative (Woodman et al., 1993). Unlike other elements of an innovative culture, creativity may occur primarily at an individual level rather than a group level; it is often easier to come up with a novel and useful idea alone than in a group situation. It is essential, however, that church leaders learn of creative ideas in order to evaluate their relevance to their context; these ideas do not need to come from the leaders themselves, nor do they need to come from within their churches. This is one of the main benefits of being a member of a network of churches (e.g., a denomination) or a network of Christian leaders (either a local network or a national association, such as the Great Commission Research Network). Similarly, reading contemporary ministry-focused literature can be an important source of innovative ideas.

Organizational Openness. It is not enough for leaders simply to be exposed to new, creative ideas to implement innovations. The organization, including the various people in leadership and other stakeholders, needs to be open to new ideas, responding to them with flexibility, and the ability to adapt them to the current situation (de Dreu \& West, 2001; Hurley \& Hult, 1998; Ruvio et al., 2014). In churches, this means that leaders need to learn about the needs and experiences of their target audience, not just in broad theological terms, but in their specific cultural context to offer innovative programs and activities that can respond to these needs. It also means that there must be a willingness to let go of what has worked in the past but is no longer bringing the church closer to accomplishing its 
mission. Leaders must be receptive to new ideas, open to other points of view, tolerant of ambiguity and uncertainty, and evaluate ideas using context-specific principles, while remaining faithful to biblical principles which do not vary according to context. When leaders are chosen and as they are developed, openness to new ideas is essential for being able to move from the creativity stage to the implementation stage of innovation.

Future Orientation. Churches that can focus on their future course of actions rather than the past are more likely to be innovative than churches that continually refer to what has worked in the past (Hult et al., 2004; Ruvio et al., 2014). If leaders can foresee what is likely to happen in the church and the culture in general, they will be better able to implement the innovations necessary to best achieve the church's mission. For example, if the church believes that it will become increasingly difficult for individuals to make a stand for Christ and defend what they believe because of the increasing role of social media (Dunaetz, 2019), programs and activities can be developed to respond to the developing needs. A large part of having a successful future orientation is goal setting (Dunaetz, 2013; Latham \& Locke, 1991; Locke et al., 1984; Locke \& Latham, 1990). Fixing goals for carrying out specific tasks by a specific time usually generates better results than simply attempting to do one's best. Goals need to be revised regularly and to be set for things that leaders can control (e.g., providing 10 teaching sessions per year on why some aspect of Christianity is credible) than things that they cannot control (e.g., 50 conversions per year).

Risk Taking. Once a church experiences a period of success, it can become quite threatening to start instituting changes, even if what has worked in the past is no longer producing the fruit that it once did. However, the more a church is willing to commit resources to programs and personnel when the outcome is not sure, the more likely the church is to be innovative (Hult et al., 2004; Miller \& Friesen, 1978; Ruvio et al., 2014). The main problem with risk-taking is that it often results in failure. Clear thinking, wisdom, and gathering all the information one can beforehand may reduce the risk of failure, but it cannot eliminate it if the outcome is genuinely not known. After a failure, it is important to honestly evaluate the outcome (e.g., start by admitting that a new program did not achieve its purposes), learn from the experience, reevaluate if there are any benefits that justify continuing in the same direction, and undo or adapt the changes made if appropriate.

Proactiveness. Churches that are proactive, those which actively search for and plan activities to minister to new audiences, are more likely to be innovative than churches that focus more on problem-solving. The 
present problems of a church can easily expand to use all the leaders' time and resources. However, proactive leaders will not let present problems monopolize their time but will continue to work on new projects and touch new people. Proactiveness is fundamental to being a missional church (Guder, 1998; Stetzer, 2006; Van Gelder \& Zscheile, 2011). However, proactive ministry needs to be focused on accomplishing the mission of the church. It is not rare for a church to emphasize missional activities where the goal is outreach, that is, developing relationships with nonChristians outside the church. However, outreach without evangelism and disciple-making cannot be considered successful. It may even be a sign of an unhealthy church (Dunaetz \& Priddy, 2014).

\section{Social Ties}

Recent research on innovation in organizations has focused on the important role that social ties and social capital play (Hasan et al., 2020; Kim \& Shim, 2018; Zheng, 2010). When there are strong relationships between people within an organization, and even between people in different organizations, innovation is much more likely to be successful. Social capital can be defined as "the sum of the actual and potential resources embedded within, available through, and derived from the network of relations possessed by an individual or a social unit" (Nahapiet \& Ghoshal, 1998, p. 243), or more generally as "social networks and the norms of reciprocity and trustworthiness that arise from them" (Putnam, 2000, p. 19).

There are several reasons that social ties and capital are so important for innovation, especially in churches. Whenever an innovation is introduced in a church, there are costs involved. For example, people might regret the loss of a former program, or some new activity might make them feel ill at ease. These potential costs reduce people's willingness to participate in the innovation and may even encourage them to leave the church. However, when a person has strong relationships with others in the church, the costs are reduced (Powell \& Pepper, 2018). For example, people who are close to others have access to more information than people who have few connections with others; this information can help them better understand the value of the change and how to navigate it. Moreover, people value high-quality relationships and do not want to lose them, so they will be more willing to stay in the church when changes become difficult. Close relationships with others also permit church members to directly observe how others navigate the changes, providing them with a model that they can follow (Bandura, 1977; Frayne \& Latham, 1987). These examples all demonstrate the importance of social capital in 
a typical church member's response to innovation. But the leader's social capital maybe even more important.

It has already been noted that a pastor's social connections (e.g., within a denomination) may be an important source of creative ideas. But close relationships with other church leaders also permit the pastor to discuss, better understand, and refine an idea before introducing it to the church, making it more likely to produce the desired results. Pastors without such social capital (e.g., pastors who only come across new ideas through what they read) are handicapped because they are more limited in how they can discuss the ideas with other church leaders (Kim \& Shim, 2018; Zheng, 2010). Moreover, introducing innovation into a church can be threatening to individuals who benefit from maintaining the status quo. The strength of relationships that church leaders have with others in the church will help them survive the opposition which may occur, which often includes very painful insinuations and false accusations (Rucker \& Petty, 2003; Tanner et al., 2012).

In this model of church innovation (Figure 1), an arrow points from social capital to the arrow going from "Innovation" to "Progress toward Accomplishing Mission." This means that social capital moderates (changes) the relationship between the introduction of innovations and accomplishing the church's mission. By itself, social capital does not contribute to innovation or toward accomplishing the church's mission; rather, it strengthens the relationship between innovation and mission accomplishment. It can be viewed as a water spigot; when social capital is high, the spigot is open, and innovations can have a very positive effect. When social capital is low, the spigot is closed or nearly closed, limiting the positive effect that an innovation can produce. For leaders, this means that the ability to lead is influenced by the quality of the relationship between the follower and the leader.

In this issue of the Great Commission Research Journal, we present several innovations that churches implemented during the COVID-19 pandemic. Surprisingly, all of the submissions came from small churches with under 250 people. However, this is in line with Powell and Pepper's (2019) study of 2800 Australian churches which found that church size was slightly (but significantly) negatively related to church innovativeness; larger churches had lower innovativeness than smaller churches. Although large churches have far more resources to experiment with new ideas and technologies, the social connections between members (Powell and Pepper, 2019) are much lower in large churches than in small churches. In large churches, overall levels of commitment may be lower (Dunaetz, Cullum, et al., 2018; von der Ruhr \& Daniels, 2012) and attenders may 
decide to stop coming more easily since they have fewer and weaker social connections to keep them in the church and to help them navigate the innovations that are introduced.

\section{Program Loss}

The final element in this model of church innovation (Figure 1) is program loss, the elements of a church's program that contribute to accomplishing its mission but which are lost when new programs and other innovations are introduced. Although church leaders do not like to think that their innovations cause losses, humility requires admitting that this may be the case. Examples include changes in depth of biblical exposition that occurred when small group Bible studies replaced Sunday evening services (Rynsburger \& Lamport, 2008; Wuthnow, 1994) and the shift in theological emphases when contemporary worship songs replaced historic hymns (Livengood \& Ledoux Book, 2004; Ruth, 2015). Whenever innovations are introduced, wise leaders will listen to people's concerns and consider the potential losses that they might incur; sometimes listening and understanding are all that is necessary to help an innovation gain acceptance, especially when relationships are solid.

\section{Conclusion}

The model of church innovation in this paper (Figure 1) presents a theoretical framework for thinking about innovation in churches. Innovation is far more complex than responding to crises that occur outside of the church, such as the COVID-19 pandemic. Church leaders need to have a clear understanding of the mission that they are trying to accomplish in the church. They must also be constantly learning about the evolving cultural environment that influences church members continually. Church leaders should develop a culture of innovation in a church which will make the generation and implementation of new ideas more likely. Leaders must also consider the cost of implementing innovation. An especially important factor is the social capital of church members which will enable them to navigate and endure the hardships that innovation might bring.

Although innovation can be complex and risky, the needs of a world without Christ demand that we continue to seek out new ways to fulfill Jesus' Great Commission and help people discover how they can know and follow him.

David R. Dunaetz, General Editor 


\section{References}

Adams, G., Anderson, S. L., \& Adonu, J. K. (2004). The cultural grounding of closeness and intimacy. In D. J. Mashek \& A. Aron (Eds.), The handbook of closeness and intimacy (pp. 321-339). Erlbaum.

Anderson, D. (2021). Digital monastic communities at Sumter Chapel, Americus, Georgia. Great Commission Research Journal, 13(2), 85-88.

Anderson, N., Potočnik, K., \& Zhou, J. (2014). Innovation and creativity in organizations: A state-of-the-science review, prospective commentary, and guiding framework. Journal of Management, 4O(5), 1297-1333.

Bandura, A. (1977). Social learning theory. Prentice Hall

Bowles, J. (2021). How Zoom defied its critics and became the go-to video conferencing app for surviving the pandemic. https://diginomica.com/how-zoom-defied-its-critics-and-became-govideo-conferencing-app-surviving-pandemic

Campbell, W. K., Hoffman, B. J., Campbell, S. M., \& Marchisio, G. (2011). Narcissism in organizational contexts. Human Resource Management Review, 21(4), 268-284.

Church Relevance. (2013). 50 examples of church mission statements. https://www.churchrelevance.com/2013/03/28/50-examples-ofchurch-mission-statements/

Colleoni, E., Rozza, A., \& Arvidsson, A. (2014). Echo chamber or public sphere? Predicting political orientation and measuring political homophily in Twitter using big data. Journal of Communication, 64(2), 317-332.

Covarrubias, A., Dunaetz, D. R., \& Dykes, W. (2021). Innovativeness and church commitment: What innovations were most important during the pandemic? Great Commission Research Journal, 13(2), 49-70.

de Dreu, C. K. W., \& West, M. A. (2001). Minority dissent and team innovation: The importance of participation in decision making. Journal of Applied Psychology, 86(6), 1191-1201.

Dunaetz, D. R. (2013). Goals and accountability for ministry effectiveness: Insights from psychological science. Dharma Deepika: A South Asian Journal of Missiological Research, 17(1), 66-79.

Dunaetz, D. R. (2016). Missio-logoi and faith: Factors that influence attitude certainty. Missiology: An International Review, 44(1), 66-77.

Dunaetz, D. R. (2019). Evangelism, social media, and the mum effect. Evangelical Review of Theology, 43(2), 138-151.

Dunaetz, D. R., Cullum, M., \& Barron, E. (2018). Church size, pastoral humility, and member characteristics as predictors of church commitment. Theology of Leadership Journal, 1(2), 125-138.

Dunaetz, D. R., Jung, H. L., \& Lambert, S. S. (2018). Do larger churches tolerate pastoral narcissism more than smaller churches? Great Commission Research Journal, 10(1), 69-89.

Dunaetz, D. R., \& Priddy, K. E. (2014). Pastoral attitudes that predict numerical Church Growth. Great Commission Research Journal, 5, 241-256.

Ellul, J. (1954). La technique ou l'enjeu du siècle. A. Colin. 
Franks, J. (2021). The Quarantine Olympics of Cultivate Church in Athens, Alabama. Great Commission Research Journal, 13(2), 73-76.

Frayne, C. A., \& Latham, G. P. (1987). Application of social learning theory to employee self-management of attendance. Journal of Applied Psychology, 72(3), 387-392.

Fritsch, M., \& Meschede, M. (2001). Product innovation, process innovation, and size. Review of Industrial Organization, 19(3), 335-350.

Gopalakrishnan, S., \& Damanpour, F. (1997). A review of innovation research in economics, sociology and technology management. Omega, 25(1), 15-28.

Grapsas, S., Brummelman, E., Back, M. D., \& Denissen, J. J. A. (2020). The "why" and "how" of narcissism: A process model of narcissistic status pursuit. Perspectives on Psychological Science, 15(1), 150-172.

Grijalva, E., Harms, P. D., Newman, D. A., Gaddis, B. H., \& Fraley, R. C. (2015). Narcissism and leadership: A meta-analytic review of linear and nonlinear relationships. Personnel Psychology, 68(1), 1-47.

Guder, D. L. (Ed.). (1998). Missional church: A vision for the sending of the church in North America. William B. Eerdmans Publishing.

Hasan, I., Hoi, C.-K. S., Wu, Q., \& Zhang, H. (2020). Is social capital associated with corporate innovation? Evidence from publicly listed firms in the US. Journal of Corporate Finance, 62, 101623.

Hofstede, G. (1980). Culture's consequences: National differences in thinking and organizing. Sage.

Hult, G. T. M., Hurley, R. F., \& Knight, G. A. (2004). Innovativeness: Its antecedents and impact on business performance. Industrial Marketing Management, 33(5), 429-438.

Hurley, R. F., \& Hult, G. T. M. (1998). Innovation, market orientation, and organizational learning: An integration and empirical examination. Journal of Marketing, 62(3), 42-54.

Hurley, R. F., Hult, G. T. M., \& Knight, G. A. (2005). Innovativeness and capacity to innovate in a complexity of firm-level relationships: A response to Woodside (2004). Industrial Marketing Management, 34(3), 281-283.

Jaskyte, K. (2011). Predictors of administrative and technological innovations in nonprofit organizations. Public Administration Review, 71(1), 77-86.

Karlsen, R., Steen-Johnsen, K., Wollebæk, D., \& Enjolras, B. (2017). Echo chamber and trench warfare dynamics in online debates. European Journal of Communication, 32(3), 257-273.

Kim, N., \& Shim, C. (2018). Social capital, knowledge sharing and innovation of small-and medium-sized enterprises in a tourism cluster. International Journal of Contemporary Hospitality Management, 3o(6), 2417-2437.

Kirby, B. (2021). PreachersNSneakers: Authenticity in an age of for-profit faith and (wannabe) celebrities. Thomas Nelson.

Latham, G. P., \& Locke, E. A. (1991). Self-regulation through goal setting. Organizational Behavior and Human Decision Processes, 5O(2), 212-247. 
Livengood, M., \& Ledoux Book, C. (2004). Watering down Christianity? An examination of the use of theological words in Christian music. Journal of Media and Religion, 3(2), 119-129.

Locke, E. A., Frederick, E., Buckner, E., \& Bobko, P. (1984). Effect of previously assigned goals on self-set goals and performance. Journal of Applied Psychology, 69(4), 694-699.

Locke, E. A., \& Latham, G. P. (1990). A theory of goal setting and task performance. Prentice Hall.

Miller, D., \& Friesen, P. H. (1978). Archetypes of strategy formulation. Management Science, 24(9), 921-933.

Mullane, J. V. (2002). The mission statement is a strategic tool: When used properly. Management Decision, 4O(5), 448-455.

Nahapiet, J., \& Ghoshal, S. (1998). Social capital, intellectual capital, and the organizational advantage. Academy of Management Review, 23(2), 242-266.

Neighbour, R. W. (1973). The seven last words of the church: Or "We never tried it that way before". Zondervan Publishing House.

Norregaard, E., \& Ng, P. (2021). Making online children's ministry interactive in Wheaton, Illinois. Great Commission Research Journal, 13(2), 89-93.

Pornpitakpan, C. (2004). The persuasiveness of source credibility: A critical review of five decades' evidence. Journal of Applied Social Psychology, 34(2), 243-281.

Powell, R., \& Pepper, M. (2018). Local churches and innovativeness: An empirical study of 2800 Australian churches. Research in the Social Scientific Study of Religion, 29, 278-301.

Puls, D. (2020a). Let us prey. Cascade Books.

Puls, D. (2020b). Narcissistic pastors and the making of narcissistic churches. Great Commission Research Journal, 12(1), 67-92.

Putnam, R. D. (2000). Bowling alone: The collapse and revival of American community. Simon and Schuster.

Ransom, B., \& Moody, B. (2021). Quick responses to community needs in two churches during the pandemic. Great Commission Research Journal, 13(2), 95-98.

Rucker, D. D., \& Petty, R. E. (2003). Effects of accusations on the accuser: The moderating role of accuser culpability. Personality and Social Psychology Bulletin, 29(10), 1259-1271.

Ruth, L. (2015). Some similarities and differences between historic evangelical hymns and contemporary worship songs.”. Artistic Theologian, 3, 68-86.

Ruvio, A. A., Shoham, A., Vigoda-Gadot, E., \& Schwabsky, N. (2014). Organizational innovativeness: Construct development and crosscultural validation. Journal of Product Innovation Management, 31(5), 1004-1022. 
Rynsburger, M., \& Lamport, M. a. (2008). All the rage: How small groups are really educating Christian adults part 1: Assessing small group ministry practice: A review of the literature. Christian Education Journal, 5(1), 116-137.

Santos, H. C., Varnum, M. E. W., \& Grossmann, I. (2017). Global increases in individualism. Psychological Science, 28(9), 1228-1239.

Schein, E. H. (2004). Organizational culture and leadership (3rd ed.). Jossey-Bass

Sellers, K. (2021). Storytelling the Gospel in Hungary: Zooming in on an ancient mode of communication. Great Commission Research Journal, 13(2), 77-84.

Stetzer, E. (2006). Planting missional churches. Broadmand \& Holman.

Swales, J. M., \& Rogers, P. S. (1995). Discourse and the projection of corporate culture: The mission statement. Discourse \& Society, 6(2), 223-242.

Tanner, M. N., Zvonkovic, A. M., \& Adams, C. (2012). Forced termination of American clergy: Its effects and connection to negative well-being. Review of Religious Research, 54(1), 1-17.

Twenge, J. M., \& Campbell, W. K. (2009). The narcissism epidemic: Living in the age of entitlement. Simon and Schuster.

Twenge, J. M., \& Campbell, W. K. (2018). Cultural individualism is linked to later onset of adult-role responsibilities across time and regions. Journal of Cross-Cultural Psychology, 49(4), 673-682.

Van Gelder, C., \& Zscheile, D. J. (2011). The missional church in perspective: Mapping trends and shaping the conversation. Baker Academic.

von der Ruhr, M., \& Daniels, J. P. (2012). Examining megachurch growth: Free riding, fit, and faith. International Journal of Social Economics, 39(5), 357-372.

Woodman, R. W., Sawyer, J. E., \& Griffin, R. W. (1993). Toward a theory of organizational creativity. Academy of Management Review, 18(2), 293-321.

Wuthnow, R. (1994). Sharing the journey: Support groups and America's new quest for community. Simon and Schuster.

Zheng, W. (2010). A social capital perspective of innovation from individuals to nations: Where is empirical literature directing us? International Journal of Management Reviews, 12(2), 151-183.

Zondag, H. J. (2004). Just like other people: Narcissism among pastors. Pastoral Psychology, 52(5), 423-437 